\begin{tabular}{c|c|c}
\hline Vol. 1: 25-40, 2006 & ENDANGERED SPECIES RESEARCH & Printed November 2006 \\
Previously ESR 4: 1-16, 2004 & Endang Species Res & Published online September 17, 2004 \\
\hline \hline
\end{tabular}

\title{
Successful re-introduction of the newts Triturus cristatus and $T$. vulgaris
}

\author{
Otto Kinne* \\ Inter-Research Science Center and International Ecology Institute Nordbünte $21 \& 23,21385$ Oldendorf/Luhe, Germany
}

\begin{abstract}
The newts Triturus cristatus and T. vulgaris are endangered species. In spite of laws protecting them and their habitats in many countries, the number and size of their populations continue to decrease. Hence, protection is not enough. We must learn more about their ecology and build new homes for them by restoring old and creating new habitats. The local initiatives reported here are intended to serve as an example of assisting the newts in their fight for survival. The author studied their ecology, put an end to agricultural activities in a small section of the Luhe valley (North Germany), provided breeding ponds, summer habitats, overwintering quarters, and reduced predator pressures. Over 10 years the natural reproductive capacity of the newts was supported by releasing annually, into newly built ponds, ca.150 larvae and juveniles (about 60 T. cristatus and 90 T. vulgaris) - bred, reared and raised in own enclosures. These measures have resulted in the successful re-introduction of the newts to an area in which they had lived, presumably for a very long time, until human activities destroyed the basis of their existence and thus caused extinction.
\end{abstract}

KEY WORDS: Triturus cristatus $\cdot$ T. vulgaris $\cdot$ Re-introduction $\cdot$ Endangered amphibians

Resale or republication not permitted without written consent of the publisher

\section{INTRODUCTION}

The literature and actions concerned with the survival of newt populations in a rapidly changing world dominated by powerful human economic interests are impressive. Several projects enjoy considerable financial support and are carried out by hundreds of people. In sharp contrast the present project is supported by very limited financial resources and is carried out by only 3 people (1 scientist and 2 gardeners). We demonstrate what can be done for endangered amphibians at a level also practicable by private persons or groups of enthusiasts in all, including poor, countries.

Effective worldwide help for endangered species requires sympathy and stewardship from millions of people and the well-informed active involvement of hundred thousands. Hence, the present series of articles (ESR: Numbers 0 to 4 ) does not strictly adhere to the format of publications solely intended for scientists. It addresses a wide array of readers. The text is written in easy-to-understand short sentences, avoids scien- tific jargon, and includes background information essential for non-specialists dedicated to helping endangered life.

The crux of my message is: While based on scientific knowledge, support for endangered species must become a concern of large sections of humankind. It begins in your mind and with your actions. You can support endangered amphibians in your own garden or pond! The present article provides information that will help you to get started. Let us join forces beyond professional border lines and together approach one of the noblest aims of today's humanity: reducing and healing the wounds inflicted on nature by Homo sapiens.

\section{HISTORY}

The newts Triturus cristatus and T. vulgaris lived in the valley of the River Luhe near the village of Oldendorf/Luhe (North Germany, ca. 55 km south of Hamburg) prior to 1938 (Meyer 1982, pers. comm.). My 
searches for the newts over several years (1982 to 1988) documented that the local Luhe-valley populations of the 2 newts had become extinct. Assumed causes for such local extinction are agricultural activities: the application of insecticides and copious amounts of fertilisers, water drainage and frequent low-level mowing. Hence the author bought a small section of the Luhe valley and stopped all agricultural activities there.

According to a considerable number of publications (e.g. Krone 2001), Triturus cristatus populations are critically endangered in practically all countries they live in (except Russia). T. vulgaris is somewhat less endangered but its local extinction rates are also rapidly increasing. Worldwide, numerous causes have been listed for newt population decline and extinction: e.g. disappearance, eutrophication and pollution of breeding ponds; introduction of fish; development of pastures; increases in local predator pressures; addition of foreign predators; a variety of diseases, especially those caused by micro-organisms. While there can be no doubt about the dramatic amphibian population declines, Schmidt (2003) emphasises that exact population data must be based on methods that account for detection probabilities (see also Houlahan et al. 2000). This is difficult to achieve for species that live at low individual densities, spend most of their lives hidden from human eyes and are sensitive to disturbances, such as T. cristatus.

Both Triturus cristatus and T. vulgaris have been kept in captivity by numerous hobby herpetologists; they have provided a broad basis of knowledge on the newts' environmental, reproductive and nutritional requirements. A recent compilation of papers resulting from an international meeting of experts (Rostock, Germany, 2000) contains 27 contributions on the distribution, biology, ecology and protection of $T$. cristatus (Krone 2001).

\section{MATERIAL}

The genus Triturus exhibits considerable variability in morphological and physiological properties. It comprises between 9 and 12 species (Bucci-Innocenti et al. 1983, Frost 1985, Olgun \& Baran 1993, Arntzen \& Wallis 1999, Olgun et al. 1999).

Triturus cristatus LAURENTI, 1768 (crested newt, great crested newt, warty newt; Kammolch; Triton crêté) is, according to Blab \& Vogel (1989), the largest and most highly endangered newt species in central Europe. It prefers relatively open land, nearby forest areas and still-water bodies that are at least partly sunexposed. Triturus vulgaris LINNAEUS, 1758 (smooth newt, small crested newt, common newt; Teichmolch; Triton ponctué) is very adaptable with regard to differ- ent habitats and landscapes. Otherwise, both newt species have similar habitat and nutritional requirements.

Parental newt material was not easy to obtain. In Germany, free-living newt populations are protected by law. Help came from friends residing some $25 \mathrm{~km}$ away from Oldendorf. In their garden was an old, partly dried-up walled shaft of a well in which small animals, especially amphibians including Triturus cristatus and T. vulgaris often became trapped. The friends knew about my interest in amphibians and allowed me to collect trapped specimens. Over 3 yr I annually used 24 adults each of $T$. cristatus and T. vulgaris as parental material and released between 5 and 10 additional adults into Pond 8 and the pond in the field newt enclosure (see Fig. 1 in Kinne et al. 2004a). From 2000 to 2004 several people brought me individuals of both species trapped in cellars or produced in their aquaria. The newts were released into the ponds identified above.

\section{TRANSFORMATION OF AGRICULTURAL LAND INTO AMPHIBIAN HABITATS}

A prerequisite for successful re-introductions is control of essential properties of the land intended to serve as habitat for the organisms to be introduced. In our case this meant being free to return the land, as much as possible, to a state suitable for supporting amphibians. I therefore bought a small section of the Luhe valley and began - with the permission of officials in Oldendorf and Lüneburg and with the help of IR gardeners Jens Kunert, Thomas Masuhr (until May 2000), and Waldemar Zimmermann (starting May 2000) - to transform pastures for horses, cows and goats into a variety of amphibian habitats: 'InterResearch Land' (total area: 5.5 ha) was born. IR Land was overloaded with fertilisers. Hence we waited several years before starting the first re-introductions - $a$ time span needed anyhow for the building and maturation of ponds and overwintering quarters.

In essence, IR Land is a wet meadow area with high groundwater levels, usually at -30 to $-75 \mathrm{~cm}$. Drillings for our 2 artesian wells revealed that the bottom morphology down to $-80 \mathrm{~m}$ (created during many thousands of years by the meandering River Luhe) is complicated. We interfered as little as possible with the natural development of IR Land. There is need, however, to keep the land 'open', i.e. to cut excessive growth of trees and bushes and to reduce plant populations that thrive on the nutrient-rich ground, such as the stinging nettle Urtica dioica.

We mow, when necessary, but only in parts of the land and preferably at times when newts do not 
migrate. Walking and transporting materials are restricted to ca. 75-cm broad footpaths. Application of fertilisers, insecticides, weed killers or other potentially detrimental substances is not allowed.

Aquatic habitats. We created 14 still-water ponds (Fig. 1 in Kinne et al. 2004a) and numerous small pools. Of the 14 ponds, 11 are the result of simple excavations (no artificial lining). Due to the high groundwater level, the excavations filled with water within 1 to 3 wk. Different pond sizes, configurations, water depths, vegetation and exposure to sun and wind offer the newts a number of habitat choices.

With our help, the new ponds developed a rich submerged and floating vegetation (e.g. species of Elodea, Myriophyllum, Veronica, Lemna) and well-established emergent as well as marginal plant associations. We maintain areas of open water and plant-free parts of the water surface. Plants protect the ponds somewhat from northerly winds; at the southern pool edge we remove or cut plants higher than 20 to $30 \mathrm{~cm}$ to allow sun exposure. We try to keep the aquatic habitats free of predatory fish and to discourage water fowl from visiting, residing or nesting in our ponds (see below). Examples of ponds are illustrated in Fig. 1.

On IR Land, Triturus cristatus prefer to breed in sun exposed still-water ponds with abundant prey and plant growth, of more than $35 \mathrm{~m}^{2}$ surface area and at least $50 \mathrm{~cm}$ maximum depth. They accept larger or smaller water bodies. Running waters (ditches, rivers) are avoided. Worldwide, T. cristatus has been reported from ponds in (swampy) forests, gravel and clay pits, as well as in a variety of permanent water-bodies in fen, marsh and peat; pond dimensions may exceed $100 \mathrm{~m}^{2}$ surface area and $1.80 \mathrm{~m}$ depth.

Triturus vulgaris prefer similar but somewhat smaller and shallower ponds. In most other respects the behaviour of both newts and their ecological requirements appear to be rather similar.

In several IR ponds and in all terrestrial areas of IR Land, Triturus cristatus co-exists with T. vulgaris. This co-existence is threatened at times of insufficient food supply: T. cristatus then begins to use T. vulgaris as prey. In general, $T$. cristatus populations tend to have a lower individual density than those of $T$. vulgaris.

Newt ponds drained in late autumn or early winter revealed that a few adults of both species had remained in the water. Presumably they intended to overwinter at the pond bottom.

Terrestrial habitats. On IR Land, the terrestrial habitats selected by the newts were mostly close to their home pond, but migrating newts have been sighted up to $750 \mathrm{~m}$ away. The 'home terrestrial habitat' may be defined as an area up to $350 \mathrm{~m}$ around the home pond.

The terrestrial habitats differ in soil quality, surface height, vegetation and exposure to sun and wind.
They vary also in plant coverage and surface morphology. Some have mature trees, bushes, scrubs, rough uncut pasture, earth mounds and piles of dead wood or stones; others border on, or include, small forest areas. In spring, flowering plants, bushes and/or blooming trees attract insects. Examples are illustrated in Fig. 2.

In the majority of terrestrial IR habitats grass is allowed to attain full height and to bloom. In winter tall grass and reeds are cut to about $7 \mathrm{~cm}$. All necessary work near a pond is done, if possible, in January. During their terrestrial phase the newts hide, predominantly during daytime, under stones, moss, dead or rotting wood, roots of trees and bushes, log piles, or in earth holes. In the cold season, most newts seem to accept the overwintering quarters we created for them (see Fig. 6).

\section{PARENTAL CONTROL}

Newt breeding ponds are controlled, to a considerable degree, by the newts themselves. Such autocontrol can become fully effective only if the newt population consists of a sufficiently large number of individuals and uses a pond for a considerable period of time. In early spring adult newts enter the pond and prepare it for their offspring by consuming overwintered predators and those that newly enter the pond. I have called this phenomenon 'parental control'. Insufficient awareness of the need for parental control is likely to have been a reason why several re-introduction attempts failed in the past. Without allowing the parents to control potential predators, the re-introduced larvae or juveniles may simply have fed the predators. As their offspring grow up, most adults leave the pond, thus avoiding competition for food.

Two observations related to parental control: (1) In some IR ponds thousands of small fish, Leucaspius delineatus, had established themselves. According to our laboratory experiments, adult Triturus cristatus and T. vulgaris cannot prey on fully grown fish (too quick, too energetic) but they can readily consume juvenile fishes. In other words: they can eliminate a fish population by annually killing its offspring. Three years after the newts had begun to occupy the ponds these were free of fish. While adult $L$. delineatus cannot harm adult $T$. cristatus or T. vulgaris, they can consume young newt larvae (own aquarium observations). Here we have a potentially complex inter-relationship between newt and fish. Their roles as predator or prey depend on the chronology of pool occupation and on age/size. (2) In the laboratory I have observed adult Triturus cristatus quickly eliminate insect larvae and small leeches - predators of their offspring. 

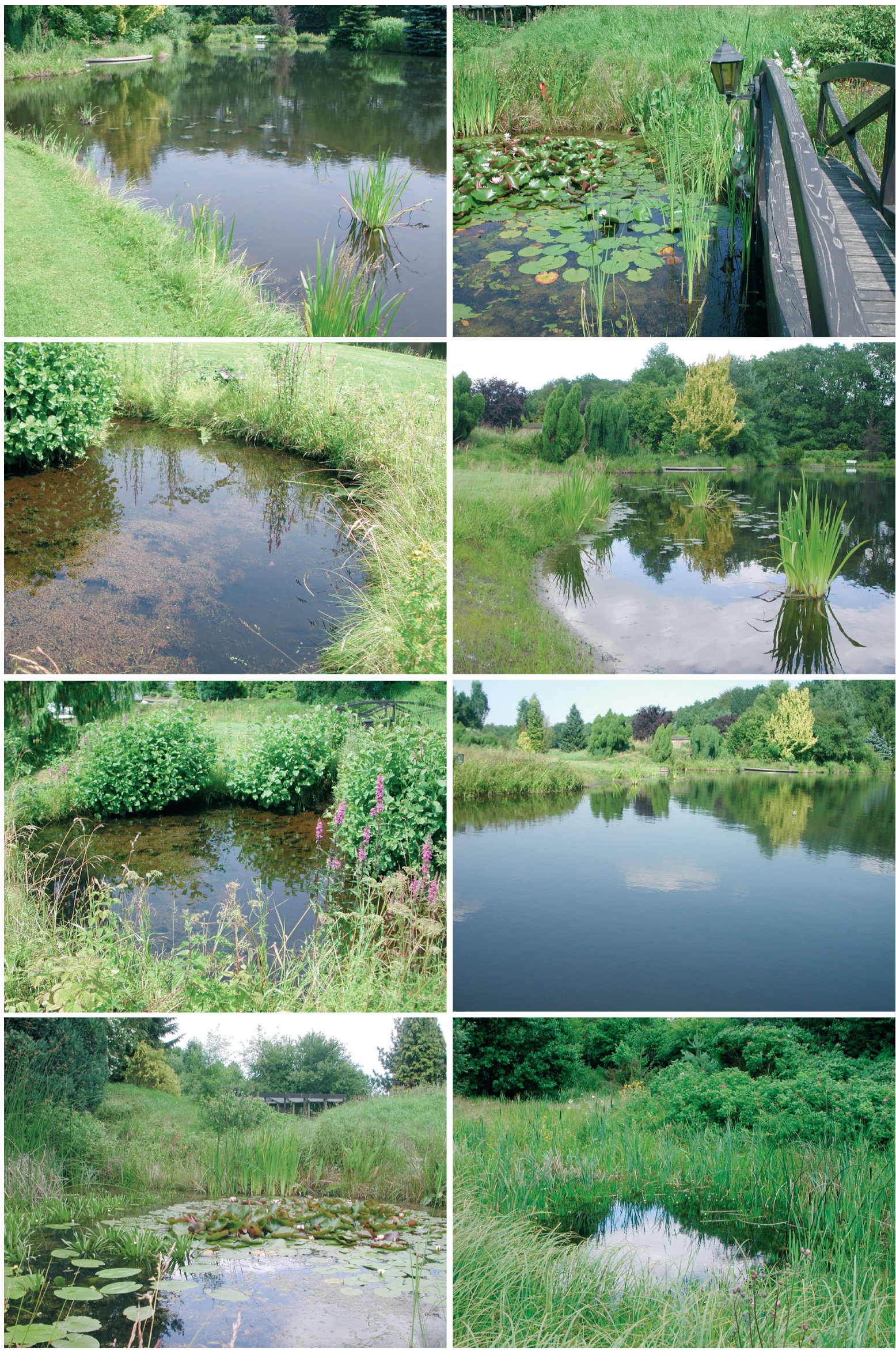

Fig. 1. Inter-Research Land: examples of aquatic habitats 

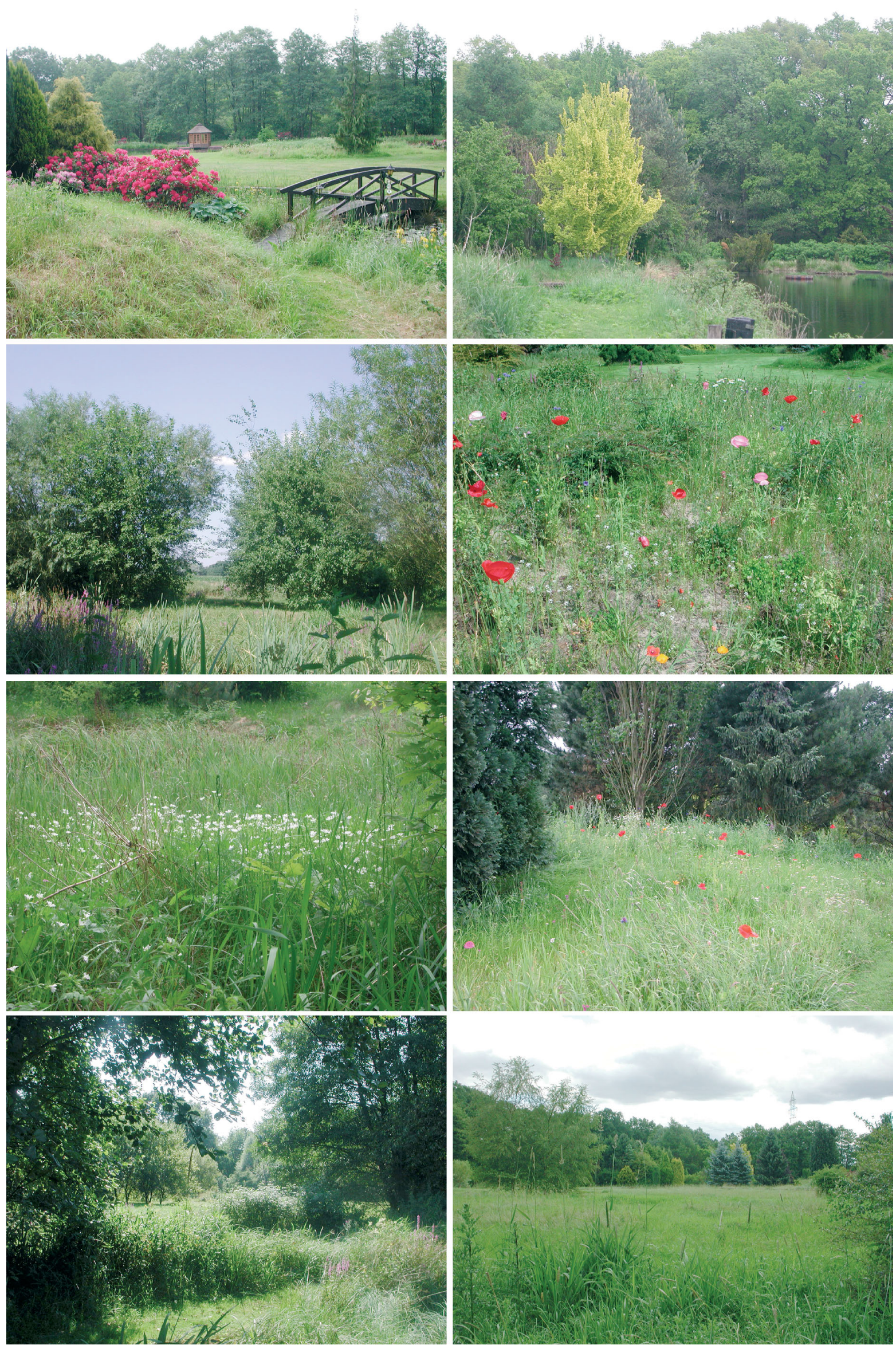

Fig. 2. Inter-Research Land: examples of terrestrial habitats 


\section{PROTECTION OF NEWT PONDS AGAINST PREDATORY BIRDS}

IR ponds are visited by birds (notably ducks Anas platyrhynchos). In spring ducks consume newt eggs and-more importantly - introduce newt predators, especially fish. Introduced as fertilised eggs, river perch Perca fluviatilis grow up surprisingly fast and can exterminate, within $2 \mathrm{yr}$, all amphibians in a pond. Hence we try to keep ducks out and empty our ponds every 3 to $5 \mathrm{yr}$ in November/December (removal of predatory fish, excessive mud and reed).

Effective protection against predatory birds is difficult. After years of testing a variety of possibilities, we found old compact electronic discs (CDs) tied to strings and suspended from bush or tree branches the best and cheapest solution (Fig. 3). The discs vary in colour and each disc is wind-moved more or less individually, sending out flashes of reflected sky-, sun-, or moonlight. While pond residents, including newts, get used to the discs, visiting birds, such as ducks Anas platyrhynchos, herons Ardea cinerea and cormorants Phalacrocorax carbo, are scared off. Following attempts to return, they finally stayed away from our ponds. In the next year, with a new generation of birds, the scenario is repeated.

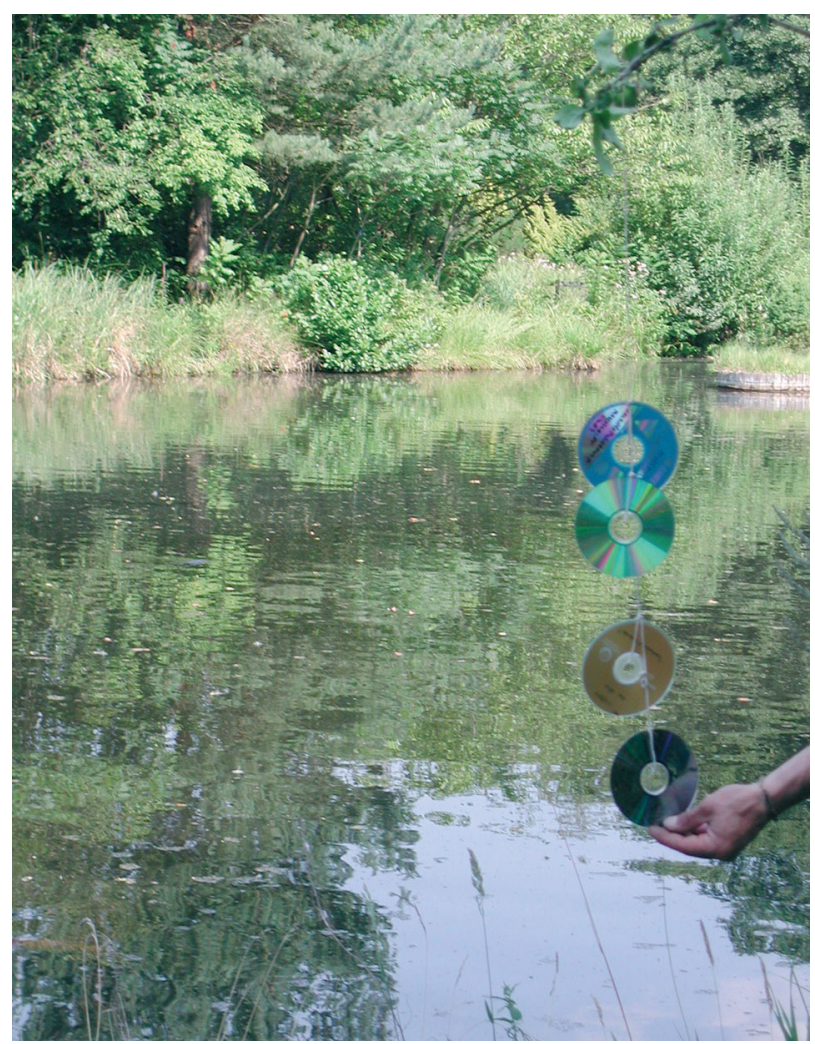

Fig. 3. The best and cheapest way to scare away predatory birds: a string of CDs hanging from a tree branch

\section{ECOLOGY}

Migration. We obtained information on migratory activities of Triturus cristatus and T. vulgaris from our amphibian fence (Fig. 4) and from occasional sightings ${ }^{1}$.

The fence extends northward from Nordbünte to the NW corner of IR Land, and from there eastward towards the River Luhe (compare Fig. 1 in Kinne et al. 2004a). It consists of fine nylon mesh supported by metal rods pushed into the ground. Along the fence we positioned open plastic pots ( $25 \mathrm{~cm}$ diameter, $35 \mathrm{~cm}$ depth) buried to their rim into the ground at intervals of $6 \mathrm{~m}$ - one on the inside, the next on the outside of the fence. Migrating amphibians (and other animals) trapped in the pots were collected daily (if necessary twice a day) and recorded. Thereafter they were released. The number of animals in inner or outer pots indicates the main migration direction. It seems unlikely that the newts emigrate from IR Land by crossing the River Luhe or the Mill Stream. Primary escape routes are westward, passing our buildings, and via the bridge we built in 1992 over the Mill Stream. We have named the bridge 'Molchbrücke' newt bridge (Fig. 5). Beyond the bridge emigrating newts encounter no barriers.

Both newt species began spring migrations in February/March, summer migrations in June/July (early August), winter migrations in (late September) October/November. No newts migrated in December and January. In general, juveniles of both species migrated faster and over longer distances than adults (see also Dolmen 1980, Müllner 2001, Münch 2001). In IR Land juveniles of the 2 newt species were usually the first to occupy our new ponds.

The author sighted migrating Triturus cristatus and T. vulgaris at night temperatures above $5^{\circ} \mathrm{C}$. Migrators prefer low light intensities, rain or high humidities. Most newts appear to travel on certain straight 'migration roads'. On these they are found more often than on other, especially less protected, routes. I sighted adult $T$. cristatus up to $700 \mathrm{~m}$ away from ponds; adult $T$. vulgaris, up to $500 \mathrm{~m}$. Kupfer (1998) recorded for 9 Triturus cristatus adults migration distances between 240 and $1290 \mathrm{~m}$. According to Kupfer \& Kneitz (2000), a single female covered a distance of $950 \mathrm{~m}$ between a forest and a pond twice within $54 \mathrm{~d}$. In the same area Kupfer \& Kneitz caught juveniles up to $860 \mathrm{~m}$ away from their assumed birth pond. Employing radio tracking, Stoefer \& Schneeweiß (2001) report that most T. cristatus migrated $10 \mathrm{~m}$ per day, occasionally 50 to $142 \mathrm{~m}$. For additional information on migration of T. cristatus consult Münch (2001).

${ }^{1}$ For an assessment of different capture techniques for Triturus cristatus consult Cresswell \& Whitworth (2004) 


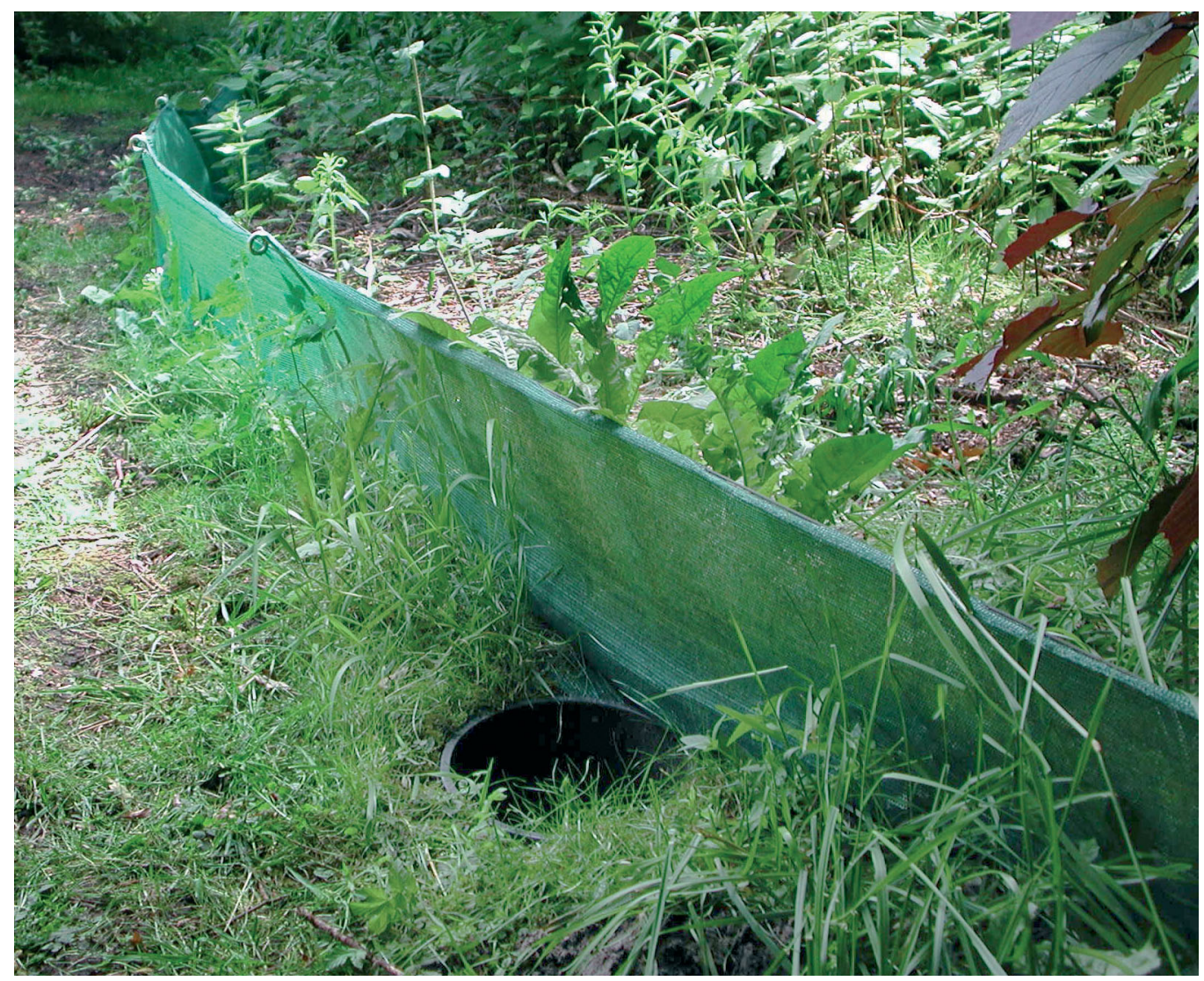

Fig. 4. Section of our amphibian fence

Overwintering. Triturus cristatus and $T$. vulgaris usually overwinter on land, sometimes in water. On land they overwinter in crevices, earth holes, amongst roots of trees or bushes, in piles of wood or in forests, i.e. in a variety of places protected from extreme low temperatures. In IR Land we have provided differently sized and shaped overwintering quarters consisting of somewhat excavated areas, usually of ca. $5 \times 8 \mathrm{~m}$, filled with parts of (rotting) tree trunks, twigs, leaves, grass, etc. and covered by a layer of cut-off plant parts. The above-ground parts of the quarters are surrounded and supported by stacked ca. $40-\mathrm{cm}$ long tree stem parts, arranged radially. Spaces between adjacent stems facilitate horizontal entry and exit of animals (Fig. 6). Decaying plant material in our overwintering quarters prevented freezing and increased the temper-
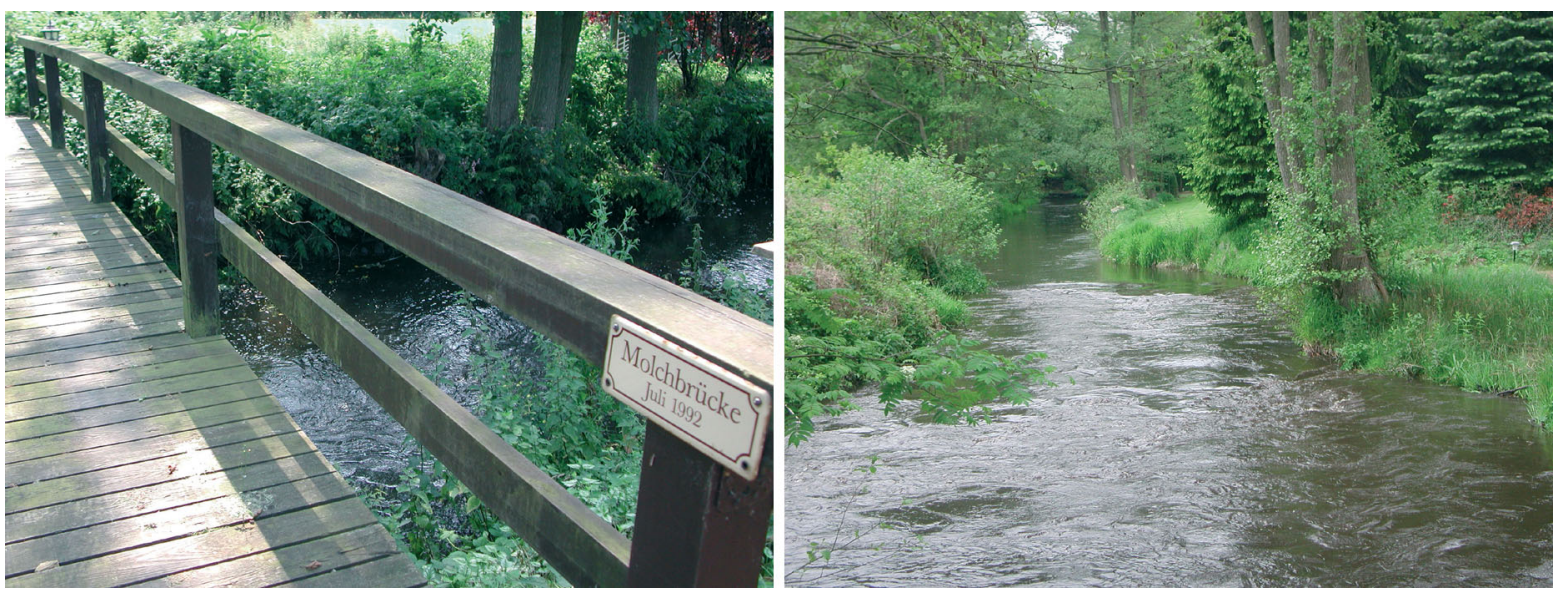

Fig. 5. Left: newt bridge across the Mill Stream; right: Mill Stream 

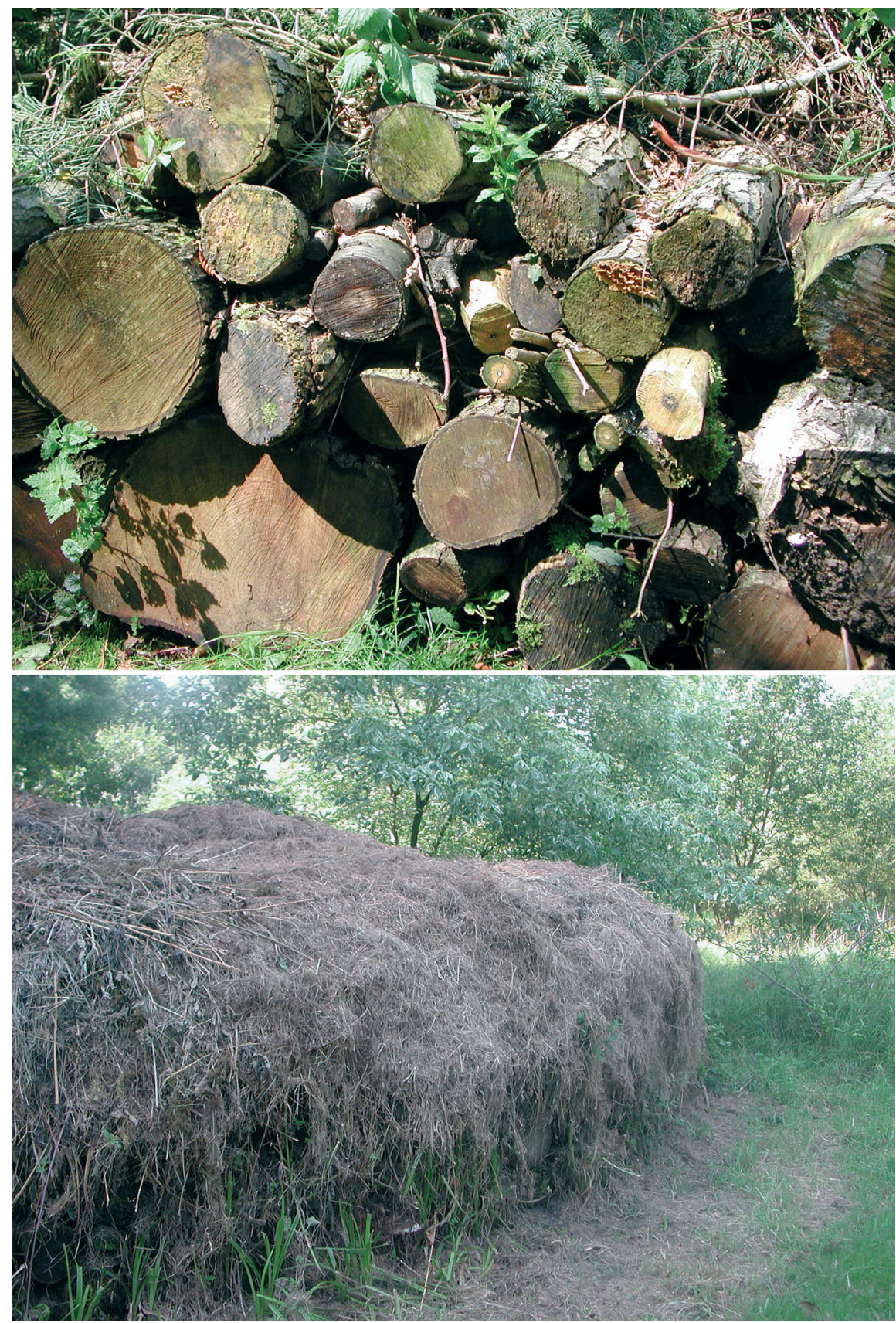

Fig. 6. Examples of overwintering quarters. Top: early stage; bottom: mature stage covered by hay

ature, as shown by repeated thermometer readings during winter.

In our laboratories, the newts overwintered in terraria $(150 \times 60 \times 60 \mathrm{~cm})$. Depending primarily on temperature, overwintering begins in October/November and ends in February/March. In the terraria all newts moved in winter to 'land areas' and hid in moist moss or grass. Immediately after overwintering, the newts prefer low light intensities (night, twilight). During their reproductive period they are both day and night active. Reproductive timings of Triturus cristatus were similar in 6 laboratory aquaria (each with 1 male and 3 females) and in the field newt enclosure (Fig. 7; ca. 25 adult males and 45 adult females).

In 1999, laboratory overwintered adult Triturus cristatus began to regain full activity in the last days of February at water temperatures (measured daily at about $12: 00 \mathrm{~h}$ ) of $8.0^{\circ} \mathrm{C}$; shortly thereafter they prepared for reproduction: from day to day males increased their crest height and females their belly cir- 

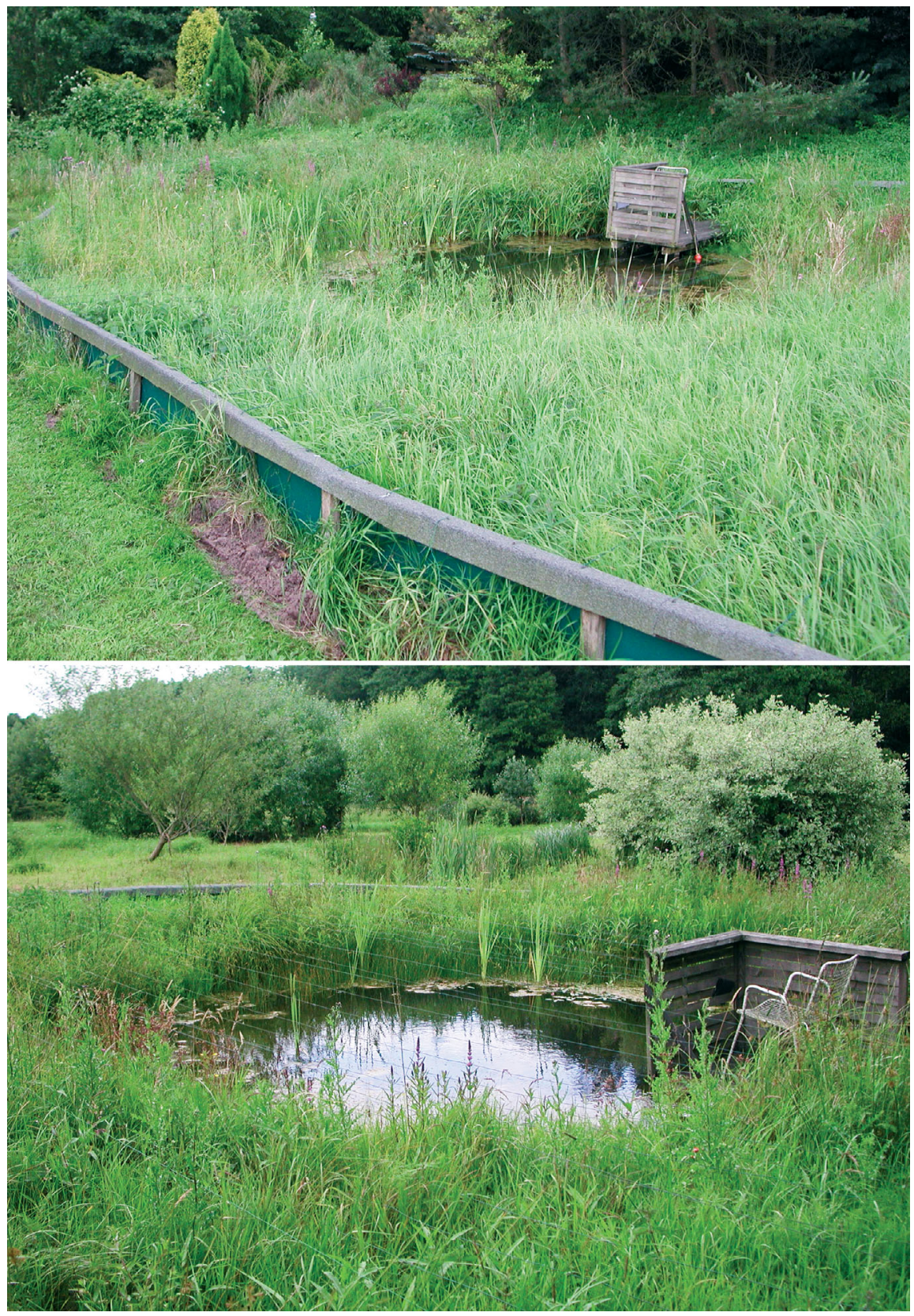

Fig. 7. Newt field enclosure (ca. $25 \mathrm{~m}$ long, $13 \mathrm{~m}$ across). Partial views. The enclosure has an aquatic and a terrestrial habitat, plus an overwintering quarter (not shown). The surrounding fence $(40 \mathrm{~cm}$ above ground, $35 \mathrm{~cm}$ below ground) consists of green (outside) and black (inside) pond lining supported by a wooden construction and topped by sharply u-bent stripes of tarpaper that prevent creeping animals from escaping or entering. The enclosure is protected against predatory birds by green wires (distance between adjacent wires: 25 to $30 \mathrm{~cm}$ ). An observation point with chair protrudes over the water surface

cumference. We fed them 1 earthworm (ca. $6 \mathrm{~cm}$ long) per newt per day. On March $1\left(9.5^{\circ} \mathrm{C}\right)$ the males had developed a crest height of 2 to $3 \mathrm{~mm}$. By March 7, all 3 males had fully developed crests and were strongly engaged in courting $\left(9^{\circ} \mathrm{C}\right)$. The first spermatophore was seen to be deposited on the ground on March $8\left(9^{\circ} \mathrm{C}\right)$.

Courtship and mating begin soon after overwintering. Several researchers have reported on aspects of newt courting and mating. The following text is based on the author's observations in the field (newt enclosure) and in the laboratory (terraria).

The males of both newt species display similar courting behaviour. They first locate and then follow a female, attempting to attract her attention by swimming ostentatiously in front of her. When the pair reaches a plant-free bottom area, the male presents a 
body side close to the female's mouth and bends in such a way that his body forms a quarter or half circle directly in front of the female. The male frequently arches its back and swims quickly forward or backward, apparently attempting to prevent the female from escaping, or to impress her. The climax of the courting procedure, the courting dance, begins with the male initiating vibrating undulations of his sharply bent tail (tail fanning) that create pressure waves and seem to propel attractants towards the female. Sometimes the male beats his tail forcefully against his own flank. He stimulates the female by repeatedly touching and nudging her with his mouth. During the courtship dance the male gradually lifts the hind part of his body until he stands almost on his head. If the female accepts the male's advances, she closes in on the male who then presents his cloaca. Thereafter, the male begins to slowly move away 'inviting' the female to follow him. Finally she touches the male's cloaca with her mouth. This is the signal for the male to deposit a spermatophore. Slowly the male leads the female towards the spermatophore. He may block the females' path by placing himself at a right angle to the female, thus stopping her and increasing the probability that she finds and takes up his spermatophore.

Reproduction in newts is well investigated. The following sections 'breeding', 'rearing' and 'raising' have the main purpose of providing practicable guidelines for people who wish to participate actively in counteracting the wordwide decrease of newts. For important literature on ethics in science consult our jounal ESEP (www.esep.de).

Breeding. The term 'breeding' comprises the developmental period from egg fertilisation to larval hatching. Breeding captive Triturus cristatus and T. vulgaris in enclosures is not difficult. Our technical culture details are similar to those used for breeding the redbellied toad Bombina bombina (Kinne et al. 2004a).

We usually placed 1 adult male and 3 adult females in one 1001 aquarium containing some Lysimachia nummularia and Veronica beccabunga (for egg attachment) as well as branches of Elodea sp. Sufficient availability of plants is important for providing hiding opportunities.

Egg laying: A fully grown female Triturus cristatus laid 150 to 380 eggs during one breeding season, $T$. vulgaris 120 to 280 eggs. The number of eggs increased with female age (size). For T. vulgaris Bell (1977) reported 100 eggs for 3-year old females, and ca. 400 eggs for 12-year old ones.

In IR ponds, the females of both newt species preferred sun-exposed vegetation in shallow water for egg laying, especially plants with broad, soft leaves (creeping jenny Lysimachia nummularia, brooklime or water speedwell Veronica beccabunga). Sitting up- right on a plant branch the female grasps a leaf with her hind legs. She then deposits a single egg. While firmly folding the leaf with her hind legs, she glues egg and leaf surface together, thus enveloping and protecting the egg. In the absence of broad-leaved plants, I have seen Triturus cristatus females to deposit eggs in bundles of filamentous algae or in/on grass shafts.

The diameter of a freshly laid Triturus cristatus egg ranges from 1.80 to $1.98 \mathrm{~mm}$, that of a $T$. vulgaris egg from 1.30 to $1.81 \mathrm{~mm}$. T. cristatus eggs can be distinguished from $T$. vulgaris eggs by their yellowish or whitish-green centre.

Embryonic development: In our labs, embryonic development took 14 to $20 \mathrm{~d}$ for Triturus cristatus, 8 to $15 \mathrm{~d}$ for $\mathrm{T}$. vulgaris $\left(18\right.$ to $21^{\circ} \mathrm{C}$ ). In larger groups of eggs (more than 60) there were always some 'early hatchers' and some 'late hatchers'. The differences in times to hatching amounted to several days under identical environmental conditions.

The glue with which the female folded the plant leaf around the egg usually dissolves at the end of the embryonic development. Over a variety of environmental conditions there is an interesting relationship between the time span from oviposition to hatching and the final dissolving of the glue. This relationship deserves investigation.

Rearing. 'Rearing' comprises the period between hatching and completion of metamorphosis. Larvae freshly hatched in our labs (early May) measured: Triturus cristatus, 10.0 to $12.1 \mathrm{~mm}$ total length (TL); T. vulgaris, 6.5 to $10.3 \mathrm{~mm} \mathrm{TL}^{2}$. They attach with their mouth region to glass plates, plants, or other solid objects. During this first phase of their life they remain largely motionless and consume their internal nutrient reserves. Later, larvae of both species eat similar food and develop in a similar way. Therefore I refer below only to Triturus cristatus.

We accommodated groups of about 60 larvae in 1001 aquaria containing filtered and gently aerated pond water. Water temperatures (usually between 18 and $22^{\circ} \mathrm{C}$ ) and day lengths followed outside conditions (open lab windows). As soon as the larvae began to swim they received and consumed micro-plankton (up to the size of freshly hatched Daphnia), collected in our ponds and sieved for size by passing the water through

\footnotetext{
${ }^{2}$ Total length is the distance between mouth tip and tail end. Our length measurements are approximations. We wanted to avoid killing the newts or disturbing (catching, handling, stretching, anesthetising) them. They were kept at naturally changing temperatures and day lengths. Hence approximations seem more appropriate than 'exact' measurements. We waited until a newt was close and parallel to the front plate of an aquarium, held the ends of a divider to mouth tip and tail end and then measured the distance between the 2 divider ends with a ruler
} 
a net. A few days after hatching the first larvae suddenly dashed vertically up to the water surface and gulped in air. Six days after hatching the larvae were fed small plankters twice a week (sieving out animals larger than adult Daphnia). After $14 \mathrm{~d}$ they measured 16 to $17 \mathrm{~mm}$ TL and now received a large variety of pond plankton among which potential predators (e.g., insect larvae) had been removed. Unless they were on a hunting trip, the larvae drifted almost motionless in open water and from time to time darted forward to catch a passing plankton organism. Occasionally they again approached the water surface and gulped air. At an age of $19 \mathrm{~d}$ the larvae measured 20 to $28 \mathrm{~mm}$ TL. In order to reduce the possibility of cannibalism they were subdivided into groups of 5 and transferred to different aquaria with lots of plants. At $25 \mathrm{~mm}$ TL and increasing water temperatures (up to $24^{\circ} \mathrm{C}$ ) air exchange at the water surface increased (apparently, the gills alone were no longer able to cover the growing oxygen demand). After $29 \mathrm{~d}$ the first pigment spots appeared on the tail, and the hind legs began to form (ca. $35 \mathrm{~mm} \mathrm{TL}$ ).

Providing the aquaria regularly with plankton promotes the growth of hydrozoans that attach to glass walls, bottom and plants. Hydra populations can quickly grow so numerous that they remove all plankters within a few hours. Hence they must be removed from time to time.

Varying considerably with temperature and food availability, metamorphosis usually begins in Triturus cristatus at an age of 7.5 to $10.5 \mathrm{wk}$, in T. vulgaris at 6.5 to $7 \mathrm{wk}$. Metamorphosis involves changes in physiology, biochemistry, morphology, and behaviour. While significant, the changes are not as dramatic as in the Anura (frogs and toads). In essence, newt larvae are small versions of adults, the most obvious difference being external gills. As lungs develop, the gills degenerate. Metamorphosis is usually completed at an age of 10 to $14 \mathrm{wk}$ in Triturus cristatus (8 to $9 \mathrm{wk}$ in T. vulgaris). For more details on larval growth and morphology of T. cristatus consult Grosse (2001).

Raising. 'Raising' comprises the period between the end of metamorphosis and the attainment of sexual maturity. Metamorphosed juveniles of Triturus cristatus begin to leave their aquatic habitat at 65 to $78 \mathrm{~mm}$ TL; juveniles of T. vulgaris, at 35 to $42 \mathrm{~mm}$ TL. At 95 $\mathrm{mm}$ TL laboratory held $T$. cristatus inhabited the land parts of their terraria. They frequently exhibited throat vibrations. The juveniles of both newt species have a strong migration drive. In the field, they may migrate quickly up to several hundred meters from their home pond. During growth to maturity, sub-adults of both species occasionally return to aquatic life. However, in the presence of abundant terrestrial food they usually remain on land. In rare cases sub-adults overwinter in water.
Age at maturity varies. In our laboratory studies sexual maturity was attained in both species in the second or 3third year after hatching. In one experiment, all of 9 well fed Triturus cristatus males, born and raised in lab containers, sexually matured in the second year of their life. Other authors report considerably longer time spans to maturity. Thus, Marnell (1998) found most Triturus vulgaris to mature after 4 winters $(4+)$; $20 \%$ of the males bred for their first time after 3 winters. Bell (1977) reported for T. vulgaris attainment of maturity between 3 and $7 \mathrm{yr}$, most individuals reproducing for the first time at an age of 6 or $7 \mathrm{yr}$.

Age and body size. These 2 parameters underlie considerable variation. Exact age determinations employ skeletochronology (e.g. Marnell 1997, 1998). The lines of arrested winter growth in the long bones, such as the phalanges of Triturus vulgaris, indicate the number of years lived, analogous to dendrological criteria used in tree-age analyses.

Studying newts in a pond in Ireland and using the skeletochronologial technique, Marnell (1998) reports that both male and female Triturus vulgaris ranged in age from $3+$ to $7+$ yr. Numerically, females dominated in the oldest age classes. For captive T. vulgaris Egener (pers. comm.) claims a maximum life span of 8 to $9 \mathrm{yr}$. According to my laboratory observations T. cristatus can live up to $10 \mathrm{yr}$.

In the current study the total body size of Triturus cristatus and $T$. vulgaris differed not only with age but also with the length of active periods (warm seasons) and food. While individuals of both species grow throughout their life, the rate of growth decreases with age. In contrast, fecundity tends to increases with age (see also Verell \& Francillon 1986, Verell et al. 1986). In the majority of newt species examined females live longer than males.

Kühnel et al. (2001) studied Triturus cristatus living in the German capital Berlin. They report maximum lengths of $168 \mathrm{~mm}$ for females and of $156 \mathrm{~mm}$ for males. Our T. cristatus attained maximum total body lengths of $173 \mathrm{~mm}$ (females), and $153 \mathrm{~mm}$ (males). In captive $T$. vulgaris Egener (pers. comm.) found a maximum body length of $14 \mathrm{~cm}$ (females) and $12 \mathrm{~cm}$ (males). For further length data consult Grosse \& Günther (1996).

Extensive and detailed statistical analyses of newt age and body size are often based on killed ('sacrificed') specimens. Large-scale killings are problematic, especially in endangered species. Fortunately, more and more scientists refrain from employing methods that require killing newts and obtain the needed data by non-lethal (albeit numerically less accurate) methods.

Food. After consuming their nutritional reserves, newt larvae begin to swim freely about in the water and to hunt for and consume micro-plankton and 
young zooplankters. Later, they eat a variety of zooplankton organisms. The larvae seem to optically recognise potential prey at a maximal distance of 6 to 9 $\mathrm{mm}$. This distance grows with increasing body length.

Sub-adults and adults are voracious predators. They have an enormous appetite and may swallow prey up to almost their own body length. Overall, the adults of both newts eat similar food. They first locate moving prey by sight (adult Triturus cristatus over distances of up to $26 \mathrm{~cm}$ ). Following closer visual examination, they employ smelling (nose contact) and then finally mouthcavity examination. Unaccepted food is spat out. The newts consume a very large variety of moving animals. Their main diet varies with the season. Examples of food organisms eaten during aquatic life are: Daphnia, Bosmina, copepods, Tubifex, mosquito larvae, isopods, amphipods, dragonfly larvae, white worms (enchytraeids), earth worms, tadpoles and, when very hungry, also their own offspring.

In order to test whether adult Triturus cristatus would eat tadpoles of the toad Bufo bufo (which are rejected by several fishes) under field conditions I added, on March 20, 2000, some 100 tadpoles to the field newt enclosure at 16:30 h. No newt showed any interest in the tadpoles until 18:00 h. Then, suddenly, a T. cristatus female approached a tadpole and took it into her mouth. Obviously she liked the taste of the tadpole and swallowed it. She then started to systematically hunt and eat tadpoles. The other newts quickly learned the lesson. With increasing intensity they too preyed on tadpoles. These, in turn, now realised the danger and began to flee. But the newts were faster and by 19:00 $\mathrm{h}$ not a single tadpole was seen in the pond. A simple test had provided proof for the presence in the newts of important feeding strategies: plasticity in prey selection, capacity of quick learning and - in the newts that later joined the females' hunt-ability to copy behaviour. The copiers had not pre-examined the food themselves; they simply trusted that what was good for the female was also good for them.

Such copying strategies remind me of experiments I conducted decades ago at the University of California at Los Angeles. For research on food conversion rates I caught desert pupfish Cyprinodon macularius in a field pond and accommodated 100 of them in 5 aquaria (20 fish each). As food for the fish I used white worms (enchytraeids), which are easy to obtain and to breed. But the fish had never seen them before in their hot (up to $40^{\circ} \mathrm{C}$ ) desert pond. In 4 aquaria the fish accepted the worms as food. But in the $5^{\text {th }}$ aquarium the fish never touched a worm for a whole week. When I finally transferred 1 fish from the other aquaria and it quickly began to feed on the worms, it took the other fish only seconds to join in. They had copied the behaviour of the new fish and learned to accept the worms as food.
Three examples document the extraordinary appetite of Triturus cristatus and T. vulgaris:

(1) A Triturus cristatus larva of $1.8 \mathrm{~cm}$ TL attempted to swallow, tail first, a Bombina bombina tadpole of equal body length. Although the predator was, of course, not able to do that, it would not let go of its prey. In the end, the wriggling tadpole lost part of its tail to the predator. Loss of tail ends (some $25 \%$ of total tail length) was observed in ca. $30 \%$ of cultured $B$. bombina tadpoles (29 individuals hatched from the same egg batch), accommodated in an $80 \mathrm{l}$ aquarium. Searches for the cause revealed the presence of $5 \mathrm{~T}$. cristatus larvae (1.4 to $1.7 \mathrm{~cm}$ TL); they must have been introduced in the form of fertilised eggs and thus escaped our attention when we added bunches of filamentous algae (which had been screened for moving animals) as potential tadpole food. Following predator removal, most of the tadpoles (1.4 to $1.8 \mathrm{~cm}$ TL) quickly regenerated their tails ${ }^{3}$. But they clearly trailed behind unhurt tadpoles in growth rate and body size. It seems possible that tadpole tails may serve as a renewable food source for young newts. In that case, repeated tail-end harvesting may retard the toad's growth to an extent where the rapidly growing young newt can swallow a tadpole whole.

(2) An apparently very hungry 8-cm long Triturus cristatus juvenile completely swallowed a 5-cm long $T$. vulgaris.

(3) An adult Triturus cristatus female of $14 \mathrm{~cm}$ length consumed an about 10-cm long leech, presumably Piscicola geometra. The leech tried to attach itself with its sucker to surrounding stones or to the female's body surface. But in the end the newt female managed to swallow the leech. I waited $20 \mathrm{~min}$ : the leech was not regurgitated.

During terrestrial life Triturus cristatus and T. vulgaris feed on practically all moving small animals they can possibly get hold of. Frequent food organisms are: worms, creeping and flying insects and small slugs.

Predators. Triturus cristatus and $T$. vulgaris are eaten by birds, mammals and fishes. Their larvae are preyed upon by insects, leeches, fishes and their own parents. Schmidt \& Van Buskirk (2001) studied the responses of $T$. cristatus larvae in the presence and absence of predatory dragonfly (Aeshna cyanea) larvae. Surprisingly, they found the newt larvae to be more active (i.e. not hiding) in the presence of the predators. For more information on newt predators consult the forthcoming Number 5 of the present series of articles.

Defence. In water, defensive flight reactions of adult newts are characterised by sudden, fast and strong tail

\footnotetext{
${ }^{3}$ In contrast, a Bombina bombina tadpole that prepared for metamorphosis was unable to regenerate lost tail parts (Kinne et al. 2004b, p. 4)
} 
beats that propel the newt towards a hiding place (e.g. beneath stones, into dense plant cover or bottom mud). On land, attacked newts defend themselves by playing dead: they bend sidewise and turn their body along its longitudinal axis, thus showing their belly. They remain in this position motionless for about 14 seconds with closed eyes, bent tail and interrupted respiratory activity. They may produce aggressive fluids and also sounds. Attacked adult Triturus cristatus wriggle and sometimes try to bite an aggressor.

Danger of disturbances due to research. Field studies on newts are essential for understanding newt ecology and for developing meaningful measures for newt protection and support. However, a number of field studies focus to such an extent on catching, handling and killing newts that they constitute a considerable disturbance for newt populations.

My work with Triturus cristatus and T. vulgaris indicates that these animals respond very sensitively to disturbances. Such potential sensitivities require critical examination. In any case, it seems appropriate for investigators to handle newts with respect and care.

\section{PRODUCING OFFSPRING FOR RE-INTRODUCTION}

This section refers to Triturus cristatus. The procedures adopted for $T$. vulgaris were similar. However, the smooth newt was able to establish permanent populations on IR Land with less help from us.

Three years of comparing the reproductive performances of Triturus cristatus in the laboratory and in the field enclosure documented that reproduction in the lab was significantly less effective than in the field. The reasons for lower reproductive performance in the lab are not known. I hypothesise that lack of direct sun exposure and insufficiently diverse food are major factors. Transfer of lab newts to the outside resulted within hours (sometimes within minutes) in darkened body colour. Upon transfer back to the lab, the body colour returned to pre-experiment conditions.

The need to support the re-introduction of Triturus cristatus over years by adding substantial numbers of larvae and juveniles to the ponds required a combination of field and laboratory techniques: We placed bundles of cut-off branches of Veronica beccabunga in plastic pots (ca. $9 \mathrm{~cm}$ diameter, $10 \mathrm{~cm}$ height) and secured the plants by adding gravel and a top layer of small stones. Then we selected suitable sun exposed places for positioning the pots in the field newt enclosure (Fig. 7), about 4 to $10 \mathrm{~cm}$ water above the highest leaves. The females soon began to deposit eggs on the plants. I saw up to 3 females sitting upright on the branches of one plant bundle, busily laying eggs for hours. As soon as some 60 eggs were laid (easy to judge by the number of folded leaves) the pot was transferred to a 1001 laboratory aquarium, containing filtered water from the field enclosure. The aquarium water was gently aerated and maintained at a temperature of ca. $20^{\circ} \mathrm{C}$. Larval hatching and raising proceeded as already reported. From June/July to September we transferred larvae and juveniles to ponds, and we repeated such additions over years (see below). The combination of field and laboratory offspring production, the offspring releases over several years, and the reduction of predator pressures comprise the crux of our re-introduction success.

\section{STATUS OF RE-INTRODUCTIONS}

The re-introduction program started in June 1994. From then on we annually released about 60 Triturus cristatus and $90 \mathrm{~T}$. vulgaris larvae and juveniles into Pond 8 and the pond in the field newt enclosure. Over 2 yr, our re-introduction attempts did not show any positive results. In fact, it was very discouraging to produce and release newts and to never see them again. Success became visible after $3 \mathrm{yr}$, and after 4 yr we recorded the first newts in ponds into which we had never released them: the newts had begun to increase their distribution areas. T. vulgaris was faster in conquering new habitats than $T$. cristatus. One reason may have been the fact that larger numbers of the smooth newt were released (simply because we obtained more larvae and juveniles from our laboratory cultures). But over the years it became evident that $T$. vulgaris can adapt more quickly to new situations and hence is more successful in conquering new habitats than T. cristatus.

Since 1999 Triturus cristatus and T. vulgaris populations have firmly established themselves on IR Land. Originally introduced to only 2 ponds, both newts have been breeding for several years in Ponds 2, 3, 4, 5, 8, 9, 12,14 and in the field newt enclosure pond. They now occupy, albeit at low individual densities, practically all terrestrial habitats of IR Land. For details on number, location and configuration of ponds consult Fig. 1 in Kinne et al. (2004a).

As already mentioned, we record migratory activities of the newts by pot traps of our amphibian fence. Since 2002 fence records document that the newts emigrate from IR Land into surrounding areas. During migration periods increasing numbers of newts fell into pots inside the fence: they were about to leave IR Land. During 2003 and 2004 neighbours brought us adults of both species found on their lots (aquatic and terrestrial habitats) up to $4 \mathrm{~km}$ away. None of the neighbours had ever seen newts in their lots before! The distribution area of our newts is now estimated to extend over about 12 ha. 


\section{DISCUSSION}

Much has been done to protect newts. An outstanding example are the programs and actions in the United Kingdom, which is home to many thousands of Triturus cristatus populations (e.g. Swan \& Oldham 1997, Gent 2001, English Nature 2004). Gent (2001) underlines the need for comprehensive conservation concepts that cover the full range of issues and actions ranging 'from the political, through species and habitat protection and management, to science and education' (p. 295). He advocates an action plan to bring about 100 re-colonisations each year. I am in full agreement with Gent including his statement: Triturus cristatrus cannot be 'sustained at a favourable conservation status through site protection alone: we are looking to a full package of measure(s) that cannot be achieved only by the Natura 2000 series. These measures need to address both political and ecological issues.' (p. 304).

The genus Triturus lives in Europe and Asia (Thorn 1968, Griffiths 1996). Exact details on current distributions of T. cristatus and T. vulgaris are rare. While the majority of experts agree that distribution areas decline with increasing speed, most assessments on newt population dynamic lack statements of detection probabilities (Schmidt 2003). This is especially problematic for $T$. cristatus, a species known for a rather reclusive way of life.

Two examples of newt population declines: (1) While widely distributed in northern Switzerland in the 19th century, today Triturus cristatus is extinct in 9 cantons and rare in most parts of western, northern and central areas of the country; of a total of 340 site records, currently only 100 could be confirmed, in 80 sites the newt has definitely disappeared (Grossenbacher \& Zumbach 2001). (2) For Russia, the home of about half of the T. cristatus world population, distribution data have been published by Kuzmin (2001). He states that the crested newt is not severely endangered in most Russian habitats, but that increasing danger comes from the introduced exotic fish Perccottus glehni. Presently, this fish is rapidly increasing its range.

Courting and reproduction in newts - the key to population survival-are complex and fascinating. Most previous publications are confirmed by my own research. While the male initiates courting, the selection of the partner in newts is a female affair. Sexual selection in the genus Triturus has received attention by Halliday (1977). The females seem to employ combinations of visual, olfactory and vibration cues as criteria. Gabor \& Halliday (1997) reported multiple mating in Triturus vulgaris vulgaris. Their hypothesis predicts that female 'choosiness' increases as the breeding season progresses. An early female mating choice would facilitate early egg laying; a later, more choosy choice, the chance of mating with 'higher quality' males. Garner \& Schmidt (2003) investigated female mate choice in $T$. alpestris (they also present a list of pertinent publications). Similar to Gabor \& Halliday, Garner \& Schmidt hypothesise that females mate initially to ensure fertilisation, and later select genetically less related males. Newt females appear to assess mate quality in terms of physical power, body size, courting skill and dorsal crest development. An essay on sexual selection has been published by Andersson (1994).

In Triturus cristatus, Wallace \& Wallace (2000) recorded a1:1 sex ratio at 18 to $24^{\circ} \mathrm{C}$. Higher temperatures led to more males than females. Lower temperatures caused significant female excess. The authors assume that extreme temperatures perturb the normal $\mathrm{XX} / \mathrm{XY}$ system of sex determination in favour of either an ancestral ZZ/ZW system or a still 'more primitive' direct environmental control. Bell (1977) reported from young Triturus vulgaris a sex ratio near equality, but in older adults, females were more numerous. Bell sees the reason for this growing imbalance in the greater mortality of adult males.

In Germany Triturus cristatus occupies a considerable variety of terrestrial habitats (Günther 1996, Kupfer \& von Bülow 2001, Podloucky 2001, Köstermeyer 2002). Müllner (2001) paid special attention to the importance of the quality of terrestrial habitats for $T$. cristatus and $T$. vulgaris. Comparing a woodland and a grassland site she found a clear preference for the woodland (forest) site. It provided more structural diversity and thus better shelter, and a micro climate with higher humidity levels.

Population size is crucial for newt population development and survival. It is a determinant of genetic diversity. Some herpetologists, e.g. Blab \& Vogel (1996), have come to the conclusion that Triturus cristatus needs very large living areas for successful long-term reproduction, i.e. for maintaining a high genetic diversity. According to Blab \& Vogel, single newt populations require a minimum living space (aquatic plus terrestrial) of 50 ha. Gene exchanges between several such areas are considered necessary to avoid detrimental inbreeding effects. The total living space needed for long-term survival would then amount to many hundreds of hectares. Jehle \& Arntzen (2001) argue 'that the genetic erosion of T. cristatus in human-altered landscapes is high' (p. 193) and that genetic aspects require attention in large-scale management plans. Jehle et al. (2001) studied the effective population size of syntopic $T$. cristatus and T. marmoratus. They express concerns about the long-term demographic viability of amphibian populations in situations typical for landscapes in Europe. 
A contradictory paper was published by Kühnel et al. (2001). They studied 32 Triturus cristatus populations in Berlin. Half of them lived within the urban area. Since 1978 the authors investigated individuals of 17 populations, 8 of these with more than 100 individuals. The largest population numbered 1535 adults. These investigations document the newt's ability to adapt to inner city life (like many other animals and plants). They also provide proof that $T$. cristatus can exist, over extended periods of time, in relatively small living areas.

The significance of habitat size and the need of gene exchanges across very large living areas for the survival of Triturus cristatus and T. vulgaris populations require further investigation.

\section{CONCLUSIONS}

Basic requirements for newt population survival are: availability of unpolluted summer and winter habitats, adequate humidity values and nutritional resources, protection from excessive predation and climatic extremes.

Major reasons for the continuous worldwide decline of Triturus cristatus and T. vulgaris populations are: detrimental influences of agriculture and urbanisation, declines in newt habitat quality due to promotion of recreation activities (including sport fishing), road killing, fragmentation of newt habitat areas caused by road construction, reduction in habitat quality as a consequence of large-scale landscape transformations, changes in climate dynamics, microbial diseases, and increased predator pressures.

In contrast to the worldwide declines reported by many authors our local efforts to re-introduce Triturus cristatus and $T$. vulgaris to a small valley area of the River Luhe (North Germany) have been successful.

I have conducted research on the newt's ecology and terminated agricultural impacts in a valley section of the River Luhe; provided breeding ponds, summer habitats and overwintering quarters; and supported the natural reproductive capacity of the newts over several successive years by adding enclosure-produced larvae and juveniles to breeding ponds. These efforts - together with reductions in predator pressures from birds and fishes - have resulted in the re-introduction of the newts to an area in which they had lived before, presumably for a very long time, until human activities destroyed the basis of their existence. Since 2001 the re-introduced newts occupy all terrestrial areas of IR Land. They reproduce in 9 newly created ponds and they have established populations with a natural age structure. I estimate the present (August 2004) total individual numbers to be more than 500 for
Triturus cristatus and about 1900 for T. vulgaris. Since 2002 members of the 2 newt species have begun to conquer additional terrain outside IR Land and thus to enlarge their area of distribution.

The view of several herpetologists that newts require inter-connected habitats of very large living areas (up to hundreds of hectares) for long-term survival invites critical examination. The severity of dangers to the newt's long-term existence due to inbreeding effects in small habitat areas cannot, in my opinion, be sufficiently assessed without additional research.

For examination I present 4 hypotheses: (1) Creating new habitats and introducing to them new, enclosureproduced newt larvae and juveniles compensates for original-site fidelity of adults (they migrate back to their home pond) and thus supports amphibian survival in a changing world more effectively than the protection of traditional habitats or migration routes. (2) Small areas in which newts reproduce over extended periods of time with great efficiency can be of equal-or even superior-significance for longterm species survival than very large areas of interconnected newt habitats. (3) Research focussing on extensive killing, catching and handling newts can critically disturb these sensitive animals. (4) There is a datum shift in annual amphibian life-cycle dynamics: newts, toads and frogs resume their activities earlier in the year than they used to decades ago.

Acknowledgements. Jens Kunert and Waldemar Zimmermann (IR) served as dedicated helpers, Helga Witt (IR) as indispensable assistant. Dr Clare Lehane (IR) helped by locating pertinent literature. John Austin and Matthias Seaman (both IR) copy-edited the manuscript. The Community of Oldendorf/Luhe (Mayor Günter Rund) and the District Government in Lüneburg (1. Kreisrat Dr Stefan Porwol) have helped to solve administrative problems. Dipl.Ing. Klaus Rund repeatedly assisted in communications with governmental agencies. Inter-Research Science Center paid for all projectrelated expenses. Three Anonymous Reviewers provided useful and timely reports. I am grateful for all this support.

Architecture of Inter-Research Land and photos: author.

\section{LITERATURE CITED}

Andersson M (1994) Sexual selection. Princeton University Press, Princeton, NJ

Arntzen JW, Wallis GP (1999) Geographic variation and taxonomy of crested newts (Triturus cristatus superspecies): morphological and mitochondrial DNA data. Contrib Zool 68 (3):1-16

Blab J, Vogel H (1989) Amphibien und Reptilien. Kennzeichen, Biologie, Gefährdung. BLV Verlagsgesellschaft $\mathrm{mbH}$, München

Blab J, Vogel H (1996) Amphibien und Reptilien erkennen und schützen. BLV Verlagsgesellschaft mbH, München

Bell G (1977) The life of the smooth newt (Triturus vulgaris) after metamorphosis. Ecol Monogr 47:279-299 
Bucci-Innocenti S, Ragghianti M, Mancino G (1983) Investigation of karyology and hybrids in Triturus boscai and $T$. vittatus, with a reinterpretation of the species groups within Triturus (Caudata: Salamandridae). Copeia 1983: 662-672

Cresswell W, Whitworth R (2004) An assessment of the efficiency of capture techniques and the value of different habitats for the great crested newt Triturus cristatus. Engl Nature Res Repts Number 576:1-75

Dolmen D (1980) Distribution and habitat of the smooth newt, Triturus vulgaris (L.), and the warty newt, T. cristatus (Laurenti), in Norway. Proc Eur Herpetology Symp, CWLP Oxford, p 127-139

English Nature (2004) (A series of reports concerned with conservation of wildlife and geology throughout England). English Nature, Northminster House, Peterborough

Frost DR (ed) (1985) Amphibian species of the world: a taxonomic and geographical reference. Allen Press and the Association of Systematics Collection. Lawrence, KS

Gabor C, Halliday TR (1997) Sequential mate choice by multiple mating smooth newts: females become more choosy. Behav Ecol 8:162-166

Garner TWJ, Schmidt BR (2003) Relatedness, body size and paternity in the alpine newt, Triturus alpestris. Proc R Soc Lond B 270:619-624

Gent T (2001) The conservation of the great crested newt Triturus cristatus in the UK. RANA, Sonderheft 4:295-305

Griffiths RA (1996) Newts and salamanders of Europe. T \& AD Poyser, London

Grosse WR (2001) Zur Feldbestimmung der Metamorphosestadien des Kammolches. RANA, Sonderheft 4:173-178

Grosse WR, Günther R (1996) Kammolch - Triturus cristatus (Laurenti, 1768) In: Günther R (ed) Die Amphibien und Reptilien Deutschlands. G Fischer, Jena, p 120-141

Grossenbacher K, Zumbach S (2001) Kammolche in der Schweiz (Triturus cristatus \& T. carnifex). RANA, Sonderheft 4:23-28

Günther R (1996) Die Amphibien und Reptilien Deutschlands. G Fischer, Jena

Halliday TR (1977) The courtship of European newts: an evolutionary perspective. In: DH Taylor SI Guttman (eds) The reproductive biology of amphibians. Plenum Press, New York, p 185-232

Houlahan JE, Findlay CS, Schmidt BR, Meyer, AH, Kuzmin SL (2000) Quantitative evidence for global amphibian population declines. Nature 404:752-755

Jehle R, Arntzen JW (2001) Ist der Kammolch (Triturus cristatus) genetisch gefährdet? RANA, Sonderheft 4:193-198

Jehle R, Arntzen W, Burke T, Krupa AP, Hödl W (2001) The annual number of breeding adults and the effective population size of syntopic newts (Triturus cristatus, T. marmoratus). Molec Ecol 10:839-850

Kinne O, Kunert J, Zimmermann W (2004a) Endangered species research 2: Land and equipment. Endang Species Res $2: 1-3$

Kinne O, Kunert J, Zimmermann W (2004b) Breeding, rearing and raising the redbellied toad Bombina bombina in the laboratory. Endang Species Res 3:1-13

Köstermeyer H (2002) Der Kammolch (Triturus cristatus). Egge-Weser 15:71-74

Krone A (ed) (2001) Der Kammolch (Triturus cristatus). Verbreitung, Biologie, Ökologie und Schutz. RANA, Sonderheft 4:1-341

Kühnel KD, Krone A, Schonert A (2001) Lebensräume des Kammolchs (Triturus cristatus Laurenti, 1768) im urbanen
Raum und einige populationsökologische Daten aus Berlin. RANA, Sonderheft 4:211-223

Kupfer A (1998) Wanderstrecken einzelner Kammolche (Triturus cristatus) in einem Agrarlebensraum. Z Feldherpetol 5:238-242

Kupfer A, Kneitz S (2000) Population ecology of the great crested newt Triturus cristatus in an agricultural landscape: dynamics, pond fidelity and dispersal. Z Feldherpetol 10:165-175

Kupfer A, von Bülow B (2001) Der Kammolch (Triturus cristatus) in Nordrhein-Westfalen: Verbreitung, Habitate und Gefährdung. RANA, Sonderheft 4:83-91

Kuzmin SL (2001) Current state of Triturus cristatus populations in the former Soviet Union. RANA, Sonderheft 4: $5-22$

Marnell F (1997) The use of phalanges for age determination in the smooth newt Triturus vulgaris L. Herpetol J 7:28-30

Marnell F (1998) A skeletochronological investigation of the population biology of smooth newts Triturus vulgaris $\mathrm{L}$. at a pond in Dublin, Ireland. Proc R Irish Acad 98B:31-36

Müllner A (2001) Spatial patterns of migrating great crested newts and smooth newts: the importance of the terrestrial habitat surrounding the breeding pond. RANA, Sonderheft 4:279-293

Münch D (2001) Wanderungsbeginn und Bestandsentwicklung des Kammolchs an einer Amphibientunnelanlage in Dortmund 1981-2001. RANA, Sonderheft 4:269-278

Olgun K, Baran I (1993) A systematic research on the Triturus vittatus (Gray, 1835) (Urodela: Amphibia) populations in the inner part of the Middle Black Sea Region. Turk J Zool $17: 445-456$

Olgun K, Baran I, Tok C V (1999) The taxonomic status of Triturus vulgaris (Linnaeus, 1758) populations in Western Anatolia, Turkey. Turk J Zool 23:133-140

Podloucky R (2001) Zur Verbreitung und Bestandssituation des Kammolchs Triturus cristatus in Niedersachsen, Bremen und dem südlichen Hamburg. RANA, Sonderheft 4: $51-62$

Schmidt BR, Van Buskirk J (2001) Verhalten, Wachstum und Morphologie von Kammolch-Larven in der An- und Abwesenheit von Libellenlarven. RANA, Sonderheft 4: 179-191

Schmidt BR (2003) Count data, detection probabilities, and the demography, dynamics, distribution, and decline of amphibians. CR Biologies 326:119-124

Stoefer M, Schneeweiß N (2001) Zeitliche und räumliche Verteilung der Wanderaktivitäten von Kammolchen (Triturus cristatus) in einer Agrarlandschaft Norddeutschlands. RANA, Sonderheft 4:249-268

Swan MJS, Oldham RS (1997) Pond loss and amphibians: historical perspective. In: Boothby J (ed) British pond landscape: action for protection and enhancement. Proc UK conference of the Pond Life Project, University College, Chester 7-9 September 1997. Pond Life Project, Liverpool, p 3-16

Thorn R (1968) Les salamandres d'Europe, Asie et d'Afrique du Nord. Lechevalier, Paris

Verell PA, Francillon H (1986) Body size, age and reproduction in the smooth newt Triturus vulgaris. J Zool 210:89-100

Verell PA, Halliday TR, Griffith ML (1986) The annual reproductive cycle of the smooth newt Triturus vulgaris in England. J Zool 210:101-119

Wallace HW, Wallace BMN (2000) Sex reversal of the newt Triturus cristatus reared at extreme temperatures. Int J Dev Biol 44(7):807-810 